\title{
The preparation of some heteroaromatic and aromatic aldehydes
}

\author{
Alan R. Katritzky, ${ }^{\mathrm{a}}$ Hai-Ying He, ${ }^{\mathrm{a}}$ Qiuhe Long, ${ }^{\mathrm{a}}$ Xilin Cui, ${ }^{\mathrm{a}}$ Julian Level ${ }^{\mathrm{b}}$, and Allan L. \\ Wilcox \\ ${ }^{a}$ Center for Heterocyclic Compounds, Department of Chemistry, University of Florida, \\ PO Box 117200, Gainesville, FL 32611-7200, USA \\ ${ }^{b}$ Centaur Pharmaceuticals, Inc., 484 Oakmead Parkway, \\ Sunnyvale, CA 94086, USA \\ E-mail: Katritzky@chem.ufl.edu
}

\section{Dedicated to Gurnos Jones on the occasion of his $70^{\text {th }}$ birthday}

(received 20 Dec 99; accepted 20 Aug 00; published on the web 28 Aug 00)

\begin{abstract}
Heteroaromatic $\alpha$ - and $\beta$-carboxaldehydes were prepared by the formylation with DMF of $\alpha$ lithio benzofuran, benzothiophene, $N$-methylbenzimidazole and 10-methylphenothiazine obtained by direct lithiation and $\beta$-lithio compounds from lithium-bromine exchange. Dialkoxybenzaldehydes were prepared by the formylation of dialkoxybenzenes with hexamethylenetetramine (HMTA) or by the alkylation of dihydroxybenzaldehydes with alkyl bromides or iodides.
\end{abstract}

Keywords: Heteroaromatic aldehyde synthesis, dialkoxybenzaldehyde synthesis, lithio benzofuran, lithio benzothiophene, formylation, lithium-bromine exchange

\section{Introduction}

Heteroaromatic and aromatic aldehydes carrying additional substituents are important as versatile intermediates in the pharmaceutical industry and for organic synthesis in general. Ongoing studies on the synthesis of nitrones ${ }^{1}$ required the preparation of heteroaromatic aldehydes and dialkoxybenzaldehydes. As the published methods for preparing many of these compounds are frequently low yielding and/or not suitable for large-scale preparation, ${ }^{2}$ we now report the preparation of heteroaromatic aldehydes by the lithiation-formylation approach and of dialkoxybenzaldehydes by the formylation of dialkoxy-benzenes or by the alkylation of dihydroxybenzaldehydes. 


\section{Results and Discussion}

General Procedures. $N$-Methylformanilide in the presence of $\mathrm{POCl}_{3}$ has been used for the preparation of heteroaromatic and aromatic aldehydes, ${ }^{3}$ but requires that the position of the aromatic ring, at which the formyl group is desired to be introduced, is sufficiently reactive to allow selective formylation.

Direct lithiation and subsequent formylation with DMF is a facile procedure used to prepare heteroaromatic aldehydes with the formyl group adjacent to a heteroatom, regioselectively and in good yields. For example, the lithiation of furans/benzofurans ${ }^{4 \mathrm{a}}$ and benzothiophenes ${ }^{4 \mathrm{~b}}$ always occurs at a free a-position.

Benzofuran-2-carboxaldehyde (2a), benzothiophene-2-carboxaldehyde (2b) and $N$ methylbenzimidazole-2-carboxaldehyde (2c). Bisagni et al., reported that benzofuran-2carboxaldehyde 2a was prepared in 38\% yield by the Vilsmeier formylation of benzofuran 1a with DMF and $\mathrm{POCl}_{3} .{ }^{5}$ Our work showed that direct lithiation of $1 \mathrm{a}$ with $n$-BuLi, and subsequent formylation with DMF, gave 2a in $67 \%$ yield.

Benzothiophene-2-carboxaldehyde $\mathbf{2 b}$ was previously synthesized in $62 \%$ yield by the lithiation of benzothiophene 1b, followed by the treatment with $N$-methylformanilide. ${ }^{6}$ Use of DMF instead of $N$-methylformanilide produced $\mathbf{2 b}$ in $81 \%$ yield.

Le Bris et al. ${ }^{7}$ reported the preparation of $N$-methylbenzimidazole-2-carboxaldehyde 2c in 50\% yield by the $\mathrm{SeO}_{2}$ oxidation of 1,2-dimethylbenzimidazole, however 1,2-dimethylbenzimidazole is very expensive. By using the lithiation-formylation approach, 2c was obtained in $44 \%$ yield from $N$-methylbenzimidazole.

10-Methylphenothiazine-4-carboxaldehyde (4). 10-Ethylphenothiazine-4-carboxaldehyde was previously prepared in $69 \%$ yield by lithiation of 10-ethylphenothiazine with sec-BuLi and subsequent formylation with DMF. ${ }^{8}$ However, similar treatment of 10-methylphenothiazine 3 with sec-BuLi and DMF did not afford 10-methylphenothiazine-4-carboxaldehyde 4. Using $n$ BuLi instead of sec-BuLi as a lithiation reagent gave 4 (40\%) together with two further compounds: 3 (12\%) and by-product A (22\%), which were all isolated by column chromatography (Scheme 1). The GC-MS spectra show that $\mathbf{4}$ and $\mathbf{A}$ are isomeric 10methylphenothiazine carboxaldehydes with the same molecular weight and expected mass spectra splitting patterns. By-product A was difficult to isolate, because its chromatography characterization is close to that of the starting material 3. The NMR spectrum of a small specimen of A was different from both 10-methylphenothiazine-4-carboxaldehyde and 10methylphenothiazine-3-carboxaldehyde. Since there are seven aromatic hydrogen peaks overlapped in ${ }^{1} \mathrm{H}$ NMR spectrum of $\mathbf{A}$, it is difficult to determine the position of the formyl group from the splitting patterns of its ${ }^{1} \mathrm{H}$ NMR spectrum. Therefore, we believe that $\mathbf{A}$ is either 1- or 2-formylated product. 


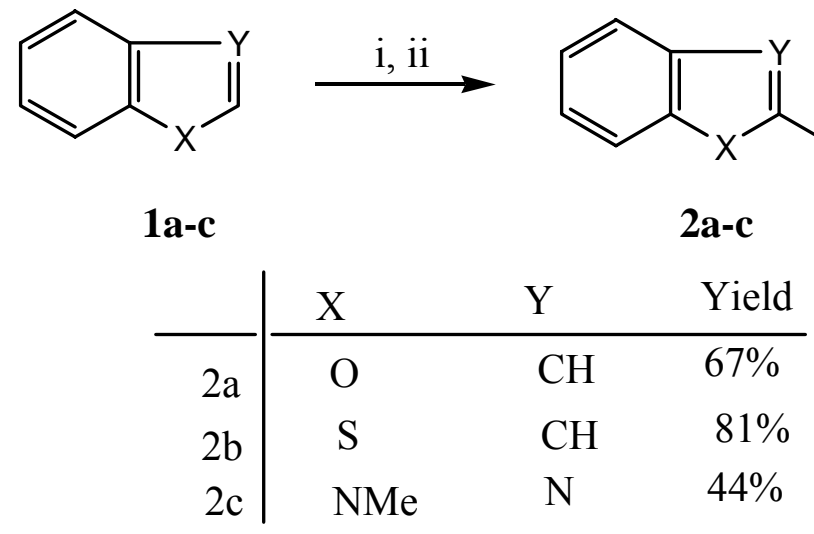

i) $n$-BuLi, THF, $-78^{\circ} \mathrm{C}, 1 \mathrm{~h}$; ii) $\mathrm{DMF},-78^{\circ} \mathrm{C}, 4 \mathrm{~h}$

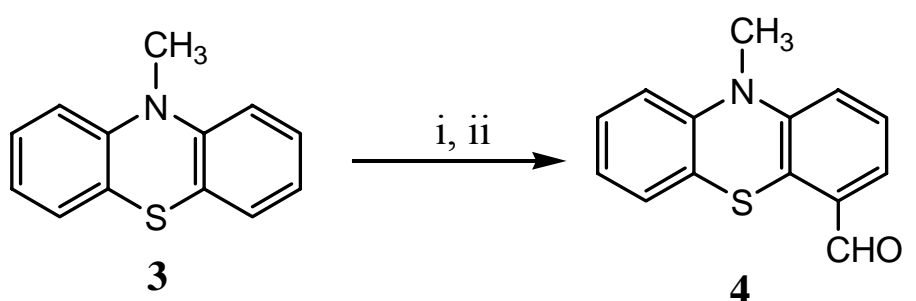

i) n-BuLi, THF, TMEDA, rt, 2 h; ii) DMF, rt, $1 \mathrm{~h}$

\section{Scheme 1}

\section{2-Ethylbenzofuran-3-carboxaldehyde (7a) and 2-methylbenzothiophene-3-carboxaldehyde} (7b). Bisagni et al. reported that 2-ethylbenzofuran-3-carboxaldehyde 7a was prepared in 66\% yield by the Vilsmeier formylation of 2-ethyl-benzofuran 5 a with DMF and $\mathrm{POCl}_{3}{ }^{5}$ but these conditions in our hands gave a complex mixture. However, bromination of $\mathbf{5 a}$, according to the literature, ${ }^{9}$ gave 3-bromo intermediate $6 \mathbf{a}$ in $67 \%$ yield. Treatment of 6a successively with $n$ BuLi and DMF gave the desired 2-ethylbenzofuran-3-carboxaldehyde 7a in 78\% yield. The bromination of 2-methylbenzothiophene $5 \mathbf{b}$, according to the reported method, ${ }^{10}$ gave 3-bromo intermediate $\mathbf{6 b}$, which was converted into 2-methylbenzothiophene-3-carboxaldehyde $7 \mathbf{b}$ in $42 \%$ yield via lithium-bromine exchange and formylation with DMF (Scheme 2).

Benzothiophene-3-carboxaldehyde 7c was previously prepared in low yield (7\%) by direct formylation of benzothiophene with $\mathrm{N}$-methylformanilide and $\mathrm{POCl}_{3}{ }^{2 \mathrm{a}}$ Campaigne et al. prepared 7c in 36\% yield from expensive 3-methylbenzothiophene in three steps. ${ }^{2 b}$ These reactions are not adaptable for large-scale preparation, as they require peroxide as a reactant and form by-products. According to the literature, ${ }^{11}$ bromination of benzothiophene $5 c$ readily gave 3-bromobenzothiophene $6 \mathrm{c}$ in $60 \%$ yield. However, ${ }^{1} \mathrm{H},{ }^{13} \mathrm{C} \mathrm{NMR}$ spectra show that the formylation of $\mathbf{6 c}$ with sec-BuLi and DMF afforded an inseparable mixture due to their close $\mathrm{R}_{\mathrm{f}}$ 
values of benzothiophene-3-carboxaldehyde 7c and benzothiophene-2-carboxaldehyde $\mathbf{2 b}$. The formation of $\mathbf{2 b}$ is presumably due to the exchange of benzothiophene-3-carbanion with the active proton at the 2-position, leading to benzothiophene-2-carbanion.

10-Methylphenothiazine-3-carboxaldehyde (9). 10-Methylphenothiazine-3-carboxaldehyde 9 was previously prepared in $60 \%$ yield by bromination of 3 with $\mathrm{Br}_{2}$, followed by the subsequent lithium-bromine exchange and formylation with DMF. ${ }^{12}$ We found that bromination of 3 with one equivalent of $\mathrm{Br}_{2}$ gave a mixture of 3, 3-bromo-10-methylphenothiazine 8 and 3,7-dibromo10-methylphenothiazine with the ratio as 2:3:1 based on the crude ${ }^{1} \mathrm{H}$ NMR spectrum. The isolated yield of $\mathbf{8}$ is $40 \%$. Treatment of $\mathbf{8}$ with sec-BuLi, and trapping the intermediate with DMF afforded 10-methylphenothiazine-3-carboxaldehyde 9 in 62\% yield (Scheme 2).

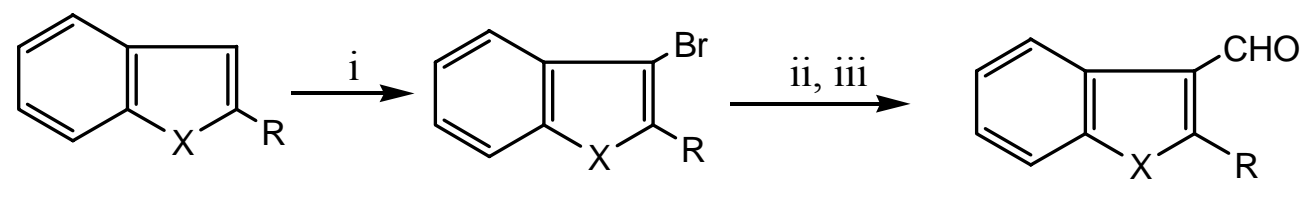

5a-c

6a-c

7a-b

\begin{tabular}{c|cccc} 
& $\mathrm{X}$ & $\mathrm{R}$ & $\mathbf{6}$ & $\mathbf{7}$ \\
\hline $\mathbf{a}$ & $\mathrm{O}$ & $\mathrm{Et}$ & $67 \%$ & $78 \%$ \\
b & $\mathrm{S}$ & $\mathrm{Me}$ & $70 \%$ & $42 \%$ \\
$\mathbf{c}$ & $\mathrm{S}$ & $\mathrm{H}$ & $60 \%$ & -
\end{tabular}

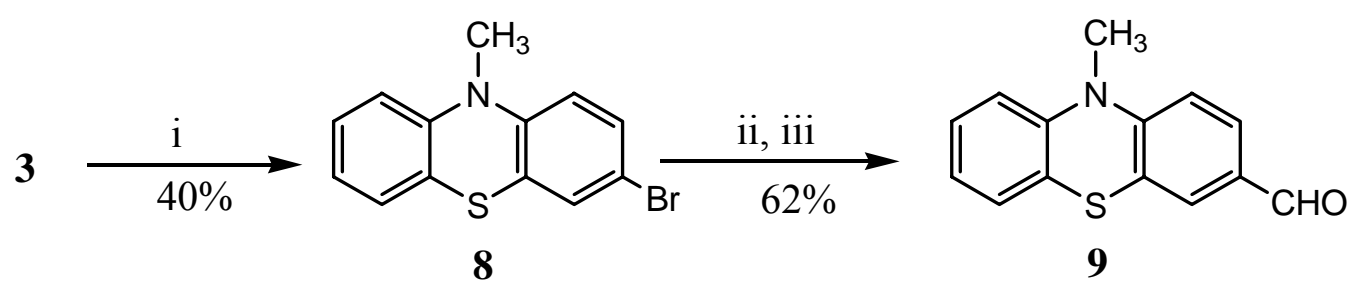

i) $\mathrm{Br}_{2}$; ii) $n$-BuLi, THF, $-78^{\circ} \mathrm{C}, 1 \mathrm{~h}$; iii) $\mathrm{DMF},-78^{\circ} \mathrm{C}, 4 \mathrm{~h}$

\section{Scheme 2}

Two general methods have been reported for the preparation of dialkoxybenzaldehydes. The first method (method A) involves direct formylation of a dialkoxybenzene with hexamethylenetetramine (HMTA): Duff found that heating phenols with HMTA in glycerol in the presence of glyceroboric acid, followed by an aqueous work up gave salicylaldehyde in rather low yields. ${ }^{13}$ Suzuki employed modified conditions with a stronger acid, such as methanesulfonic, trifluoroacetic or polyphosphoric acid as a solvent, ${ }^{14}$ which successfully introduced the formyl group onto several electron-deficient aromatic rings. ${ }^{15}$ The second method 
(method B) involves alkylation of a dihydroxybenzaldehyde with an alkyl halide under basic conditions, e.g., potassium carbonate ${ }^{16 a-c}$ or sodium ethoxide ${ }^{16 \mathrm{~d}}$ (Scheme 3).

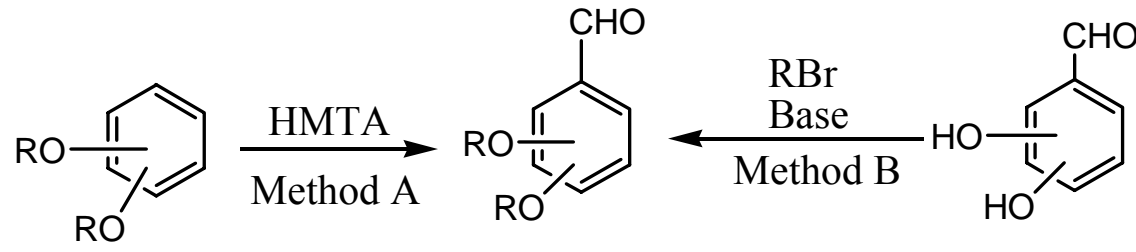<smiles>[R]Oc1ccc(C=O)c([R])c1</smiles><smiles>[R]Oc1ccc(C=O)cc1[R]</smiles><smiles>[R]Oc1ccc([R])c(C=O)c1</smiles><smiles>O=Cc1ccc2c(c1)OCCO2</smiles><smiles>O=Cc1ccc(Oc2ccc(Oc3ccccc3)cc2)cc1</smiles><smiles>O=Cc1ccc(Oc2ccc(Oc3ccc(C=O)cc3)cc2)cc1</smiles>

${ }^{a}$ Commercially available. ${ }^{b}$ Failed by using either method A or method B. ${ }^{c}$ Original target failed but gave cyclized compound $13 .{ }^{d}$ Original target failed but gave 14 and 15. Isolated yield (used method) for 10, 11 and 12

\begin{tabular}{lllll}
\hline compd & $\mathrm{R}$ & $\mathbf{1 0}$ & $\mathbf{1 1}$ & $\mathbf{1 2}$ \\
\hline a & $\mathrm{Et}$ & $48(\mathbf{A})$ & $a$ & $34(\mathbf{A})$ \\
$\mathbf{b}$ & $\mathrm{Ph}$ & $57(\mathbf{A})$ & $b$ & $(\mathbf{A})^{d}$ \\
c & $\mathrm{PhCH}_{2}$ & $67(\mathbf{B})$ & $a$ & $35(\mathbf{B})$ \\
d & $\mathrm{ClCH}_{2} \mathrm{CH}_{2}$ & $51(\mathbf{B})$ & $(\mathbf{B})^{c}$ & $b$ \\
e & $\mathrm{CH}^{\circ} \mathrm{CCH}_{2}$ & $90(\mathbf{B})$ & $74(\mathbf{B})$ & $71(\mathbf{B})$ \\
\hline
\end{tabular}

\section{Scheme 3}

Preparation of 2,4-dialkoxybenzaldehydes (10). 2,4-Diethoxybenzaldehyde 10a was prepared by the reaction of 2,4-dihydroxybenzaldehyde with ethyl iodide in the presence of sodium ethoxide. ${ }^{16 \mathrm{~d}}$ We prepared 10a in $48 \%$ yield by the formylation of 1,3-diethoxybenzene with 
HMTA. Similar HMTA formylation of 1,3-diphenoxybenzene afforded novel 2,4diphenoxybenzaldehyde 10b in 57\% yield.

According to the reported procedure, ${ }^{16 \mathrm{c}} 2,4$-bis(benzyloxy)benzaldehyde 10c was produced in $67 \%$ yield by the alkylation of 2,4-dihydroxybenzaldehyde with benzyl bromide. A similar alkylation using 1-chloro-2-bromoethane furnished the new compound 2,4-bis(2chloroethoxy)benzaldehyde 10d in 51\% yield.

Faulques et al. ${ }^{17}$ reported the preparation of 2-hydroxy-4-(2-propynyloxy)benzaldehyde by using equimolar 2,4-dihydroxy-benzaldehyde and 3-bromo-1-propyne and isolated 2,4-bis(2propynyloxy)benzaldehyde 10e as a by-product in low yield (7\%). We obtained 10e in 90\% yield with a 2.3:1 molar ratio of 3-bromo-1-propyne to 2,4-dihydroxybenzaldehyde.

Preparation of 3,4-dialkoxybenzaldehydes (11). Novel 3,4-bis(2-propynyloxy)benzaldehyde 11e was readily prepared in $74 \%$ yield by the alkylation of 3,4-dihydroxybenzaldehyde with 3 bromo-1-propyne.

Attempts to prepare 3,4-diphenoxybenzaldehyde 11b using either method A or method $\mathbf{B}$ failed. No 3,4-bis(2-chloroethoxy)benzaldehyde 11d was produced by the alkylation of 3,4dihydroxybenzaldehyde with $\mathrm{ClCH}_{2} \mathrm{CH}_{2} \mathrm{Br}$. The cyclized compound 2,3-dihydro-1,4benzodioxine-6-carboxaldehyde 13 was always obtained in up to 55\% yield under various condition of reaction temperature and solvent.

Preparation of 2,5-dialkoxybenzaldehydes (12). 2,5-Diethoxybenzaldehyde 12a was previously synthesized in $85 \%$ yield by the formylation of 1,4-diethoxybenzene with $\mathrm{SnCl}_{4}$ and $\mathrm{Cl}_{2} \mathrm{CHOCH}_{3} .{ }^{18} \mathrm{We}$ found that the HMTA formylation of 1,4-diethoxybenzene gave 12a in $34 \%$ yield. Similar alkylations of 2,5-dihydroxybenzaldehyde with benzyl bromide and 3-bromo-1propyne furnished the new compounds 12c and 12e in $35 \%$ and $71 \%$ yields, respectively (Scheme 3).

Attempts to synthesize 12d using either method A or method $\mathbf{B}$ failed. Formylation of 1,4diphenoxybenzene with HMTA to $\mathbf{1 2 b}$ introduced the formyl group onto a terminal benzene ring instead of the central benzene ring to give 4-(4-phenoxyphenoxy)benzaldehyde 14 (yield $<10 \%$ ) and 4-[4-(4-formylphenoxy)phenoxy] benzaldehyde 15 (yield $<10 \%$ ). This is presumably due to the fact that i) the central benzene ring is more hindered than the terminal ones; ii) reaction is easier in the para-position than the ortho-position; iii) the effect of a meta-phenoxy group is possibly deactivating.

In summary, multi-gram scale heteroaromatic 2-carboxaldehydes and 3-carboxaldehydes were prepared by a-lithiation or b-lithium-bromine exchange, followed by the formylation with DMF. Dialkoxybenzaldehydes were prepared either by the formylation of dialkoxybenzene with HMTA or by the alkylation of dihydroxybenzaldehydes with alkyl bromides. 


\section{Experimental Section}

General Procedures. Melting points were determined using a Bristoline hot-stage microscope and are uncorrected. ${ }^{1} \mathrm{H}$ and ${ }^{13} \mathrm{C}$ NMR spectra were recorded on a Gemini 300 NMR spectrometer (300 MHz and $75 \mathrm{MHz}$ respectively) in $\mathrm{CDCl}_{3}$ (with TMS for ${ }^{1} \mathrm{H}$ and $\mathrm{CDCl}_{3}$ for

${ }^{13} \mathrm{C}$ as the internal reference). Elemental analyses were performed on a Carlo Erba-1106 instrument.

\section{General procedure for preparation of 2a-c}

To a solution of 1a-c $(8.5 \mathrm{mmol})$ in dry THF $(40 \mathrm{~mL})$, was added dropwise $n$-BuLi $(6.0 \mathrm{~mL}, 1.42$ $\mathrm{M}$ in hexane) at $-78{ }^{\circ} \mathrm{C}$ under $\mathrm{N}_{2}$. The mixture was stirred at $-78{ }^{\circ} \mathrm{C}$ for $1 \mathrm{~h}$ and then DMF $(1.24 \mathrm{~g}, 17.0 \mathrm{mmol})$ was added. After $4 \mathrm{~h}$, the mixture was poured into aqueous $\mathrm{HCl}(4.5 \% \mathrm{w} / \mathrm{v}$, $80 \mathrm{~mL}$ ) and stirred at $0{ }^{\circ} \mathrm{C}$ for $0.5 \mathrm{~h}$. The organic phase was separated and the aqueous phase was extracted with $\mathrm{CH}_{2} \mathrm{Cl}_{2}$. The combined organic phase was dried over $\mathrm{Na}_{2} \mathrm{SO}_{4}$. After removal of the solvent in vacuo, the residue was purified by column chromatography with hexane/EtOAc as eluent to give 2a-c.

Benzofuran-2-carboxaldehyde (2a). Colorless oil (bp $\left.{ }^{5} 135{ }^{\circ} \mathrm{C} / 18 \mathrm{mmHg}\right)$; Yield, $67 \% ;{ }^{1} \mathrm{H}$ NMR : $\delta 7.31(\mathrm{t}, J=7.2 \mathrm{~Hz}, 1 \mathrm{H}), 7.46-7.57(\mathrm{~m}, 3 \mathrm{H}), 7.72(\mathrm{~d}, J=7.8 \mathrm{~Hz}, 1 \mathrm{H}), 9.84(\mathrm{~s}, 1 \mathrm{H}) ;{ }^{13} \mathrm{C}$ NMR : $\delta 112.4,117.7,123.5,124.0,126.4,129.0,152.4,156.0,179.5$. MS (EI): 146 (M, 100), 89 (80), 63 (50).

Benzothiophene-2-carboxaldehyde (2b). Colorless needles; Yield, 81\%; mp $34-35{ }^{\circ} \mathrm{C}\left(\mathrm{mp}^{6} 34-\right.$ $\left.34.5{ }^{\circ} \mathrm{C}\right) ;{ }^{1} \mathrm{H}$ NMR : $\delta$ 7.37-7.60 (m, 2H), 7.82-7.90 (m, 2H), $7.95(\mathrm{~s}, 1 \mathrm{H}), 10.05(\mathrm{~s}, 1 \mathrm{H}) ;{ }^{13} \mathrm{C}$ NMR : $\delta$ 123.1, 125.1, 126.1, 128.0, 134.4, 138.4, 142.4, 143.1, 184.5.

1-Methyl-1H-benzimidazole-2-carboxaldehyde (2c). Colorless needles; Yield, 44\%; mp 110$111{ }^{\circ} \mathrm{C}\left(\mathrm{mp}^{7} 110{ }^{\circ} \mathrm{C}\right) ;{ }^{1} \mathrm{H}$ NMR : $\delta 4.08(\mathrm{~s}, 3 \mathrm{H}), 7.36-7.45(\mathrm{~m}, 3 \mathrm{H}), 7.87-7.90(\mathrm{~m}, 1 \mathrm{H}), 10.06(\mathrm{~s}$, $1 \mathrm{H}) ;{ }^{13} \mathrm{C}$ NMR $: \delta 31.0,110.4,122.0,123.8,126.5,136.7,142.4,145.9,184.7$.

\section{General procedure for preparation of 10-methylphenothiazine-4-carboxaldehyde (4)}

To a solution of 10-methyl-10H-phenothiazine $3(2.0 \mathrm{~g}, 9.4 \mathrm{mmol})$ in dry ether $(100 \mathrm{~mL})$ was added TMEDA ( $3.0 \mathrm{~mL}, 20 \mathrm{mmol})$, followed by dropwised $n$-BuLi $(6.0 \mathrm{~mL}, 1.42 \mathrm{M}$ in hexane) at $-78{ }^{\circ} \mathrm{C}$ under $\mathrm{N}_{2}$. The mixture was stirred at $-78{ }^{\circ} \mathrm{C}$ for $2 \mathrm{~h}$ and DMF $(1.24 \mathrm{~g}, 17.0 \mathrm{mmol})$ was then added. After $1 \mathrm{~h}$, the mixture was poured into aqueous $\mathrm{HCl}(4.5 \% \mathrm{w} / \mathrm{v}, 80 \mathrm{~mL})$ and stirred at $0{ }^{\circ} \mathrm{C}$ for $0.5 \mathrm{~h}$. The ether phase was separated and the aqueous phase was extracted with $\mathrm{CH}_{2} \mathrm{Cl}_{2}$. The combined organic phase was dried over $\mathrm{Na}_{2} \mathrm{SO}_{4}$. After removal of the solvent in vacuo, the residue was separated by column chromatography with hexane/EtOAc (3:1) as eluent and then recrystallized from EtOAc to give 4 ( $0.9 \mathrm{~g}, 40 \%)$. Yellow needles; mp $110-111{ }^{\circ} \mathrm{C} ;{ }^{1} \mathrm{H}$ NMR : $\delta 3.29(\mathrm{~s}, 3 \mathrm{H}), 6.74(\mathrm{~d}, J=8.1 \mathrm{~Hz}, 1 \mathrm{H}), 6.85-6.93(\mathrm{~m}, 2 \mathrm{H}), 7.09-7.22(\mathrm{~m}, 3 \mathrm{H}), 7.37$ (d, $J=6.9$ $\mathrm{Hz}, 1 \mathrm{H}), 10.23(\mathrm{~s}, 1 \mathrm{H}) ;{ }^{13} \mathrm{C}$ NMR $: \delta 35.6,114.1,118.4,122.1,122.6,124.4,126.7,127.1,127.9$, 
128.8, 132.5, 145.6, 146.3, 190.2. Anal. Calcd for $\mathrm{C}_{14} \mathrm{H}_{11} \mathrm{NSO}$ : C, 69.68; H, 4.59; N, 5.80. Found: C, 70.01; H, 4.64; N, 5.86.

\section{General procedure for preparation of $7 \mathbf{a}, 7 \mathbf{b}$ and 9}

Sodium hydroxide (4.9 g, $123 \mathrm{mmol})$ was dissolved in glacial acetic acid (300 mL) under $\mathrm{N}_{2}$. The compound $\mathbf{5 a}$, $5 \mathbf{b}$ or $3(40 \mathrm{mmol})$ was added, followed by chloroform $(50 \mathrm{~mL})$. Bromine $(6.7 \mathrm{~g}, 40 \mathrm{mmol})$ in glacial acetic acid $(40 \mathrm{~mL})$ was added dropwise during $2 \mathrm{~h}$ at $5-10{ }^{\circ} \mathrm{C}$. The suspension was stirred at room temperature for $2 \mathrm{~h}$ and then evaporated to dryness. The residue was dissolved in $10 \% \mathrm{NaHCO}_{3}$ and $\mathrm{CH}_{2} \mathrm{Cl}_{2}$. The aqueous phase was separated and extracted with $\mathrm{CH}_{2} \mathrm{Cl}_{2}$. The combined organic phase was dried over $\mathrm{Na}_{2} \mathrm{SO}_{4}$. After removal of the solvent in vacuo, the residue was separated by column chromatography with hexane/EtOAc $(3: 1)$ as eluent to give $\mathbf{6 a}, \mathbf{6 b}$ or $\mathbf{8}$.

To a solution of the intermediate $\mathbf{6 a}, \mathbf{6 b}$ or $\mathbf{8}(6.0 \mathrm{mmol})$ in dry THF $(40 \mathrm{~mL})$, was added dropwise $s$-BuLi $\left(5.4 \mathrm{~mL}, 1.1 \mathrm{M}\right.$ in hexane) at $-78{ }^{\circ} \mathrm{C}$ under $\mathrm{N}_{2}$. The mixture was stirred at $-78{ }^{\circ} \mathrm{C}$ for $1 \mathrm{~h}$ and DMF $(0.44 \mathrm{~g}, 6.0 \mathrm{mmol})$ was then added. After $1 \mathrm{~h}$, the mixture was poured into aqueous $\mathrm{HCl}(4.5 \% \mathrm{w} / \mathrm{v}, 80 \mathrm{~mL})$ and stirred at $0{ }^{\circ} \mathrm{C}$ for $0.5 \mathrm{~h}$. The THF phase was separated and the aqueous phase was extracted with $\mathrm{CH}_{2} \mathrm{Cl}_{2}$. The combined organic phase was dried over $\mathrm{Na}_{2} \mathrm{SO}_{4}$. After removal of the solvent in vacuo, the residue was separated by column chromatography with hexane/EtOAc (3:1) as eluent to give 7a, $\mathbf{7 b}$ or $\mathbf{9}$.

3-Bromo-2-ethylbenzofuran (6a). Colorless oil; Yield, 67\%; ${ }^{1} \mathrm{H}$ NMR : $\delta 1.30(\mathrm{t}, J=7.5 \mathrm{~Hz}$, $3 \mathrm{H}), 2.80(\mathrm{q}, J=7.5 \mathrm{~Hz}, 2 \mathrm{H}), 7.20-7.30(\mathrm{~m}, 2 \mathrm{H}), 7.35-7.50(\mathrm{~m}, 2 \mathrm{H}) ;{ }^{13} \mathrm{C} \mathrm{NMR}: \delta 11.9,20.2$, 93.4, 111.0, 119.1, 123.0, 124.3, 128.4, 153.4, 156.6. MS (EI): 226 (40), 224 (40), 209 (100), 207 (100).

3-Bromo-2-methylbenzothiophene (6b). Colorless oil; Yield, 70\%; ${ }^{1} \mathrm{H}$ NMR: $\delta 2.49$ (s, 3H), 7.26-7.40 (m, 2H), 7.66-7.70 (m, 2H); ${ }^{13} \mathrm{C}$ NMR : $\delta 15.4,106.5,122.0,122.5,124.7,124.8$, $135.1,137.1,138.4$.

2-Ethylbenzofuran-3-carboxaldehyde (7a). Colorless oil; Yield, 78\%; ${ }^{1} \mathrm{H}$ NMR : $\delta 1.41(\mathrm{t}, J=$ $7.5 \mathrm{~Hz}, 3 \mathrm{H}), 3.10$ (q, $J=7.5 \mathrm{~Hz}, 2 \mathrm{H}), 7.29-7.32$ (m, 2H), 7.42-7.45 (m, 1H), 8.10-8.13 (m, 1H), $10.20(\mathrm{~s}, 1 \mathrm{H}) ;{ }^{13} \mathrm{C}$ NMR : $\delta 12.6,20.5,110.8,116.7,121.6,124.3,124.5,125.0,153.7,171.4$, 184.7. MS (EI): 174 (M, 100), 159 (45), 145 (40), 131 (50), 115 (30).

2-Methyl-benzothiophene-3-carboxaldehyde (7b). Colorless oil; Yield, 42\%; ${ }^{1} \mathrm{H}$ NMR : $\delta 2.82$ (s, 3H), 7.32 (t, $J=7.5 \mathrm{~Hz}, 1 \mathrm{H}), 7.41(\mathrm{t}, J=7.5 \mathrm{~Hz}, 1 \mathrm{H}), 7.70$ (d, $J=8.4 \mathrm{~Hz}, 1 \mathrm{H}), 8.54(\mathrm{~d}, J=$ $8.1 \mathrm{~Hz}, 1 \mathrm{H}), 10.27(\mathrm{~s}, 1 \mathrm{H}) ;{ }^{13} \mathrm{C}$ NMR : $\delta 14.1,121.4,123.5,125.0,125.7,129.8,136.6,137.1$, 157.6, 184.2. Anal. Calcd for $\mathrm{C}_{10} \mathrm{H}_{8} \mathrm{OS}$ : C, 68.15; H, 4.58. Found: C, 68.06; H, 4.47.

10-Methylphenothiazine-3-carboxaldehyde (9). Colorless needles; Yield, 62\% (based on 8); $\mathrm{mp} 86-87^{\circ} \mathrm{C}\left(\mathrm{mp}^{12} 86-87{ }^{\circ} \mathrm{C}\right) ;{ }^{1} \mathrm{H}$ NMR : $\delta 3.34$ (s, 3H), 6.74- 6.79 (m, 2H), 6.94- $6.97(\mathrm{~m}, 1 \mathrm{H})$, 7.06- $7.14(\mathrm{~m}, 2 \mathrm{H}), 7.52-7.59(\mathrm{~m}, 2 \mathrm{H}), 9.74(\mathrm{~s}, 1 \mathrm{H}) ;{ }^{13} \mathrm{C} \mathrm{NMR}: \delta 35.6,113.5,114.7,122.3$, $123.4,123.7,127.1,127.6,130.3,130.9,143.8,150.8,189.9$. 


\section{General procedure for the preparation of dialkoxybenzaldehydes}

Method A. A mixture of an appropriate dialkoxybenzene (40 mmol) and HMTA (12.8 $\mathrm{g}$, $92 \mathrm{mmol}$ ) in the solvents (given below) was heated to reflux for $3 \mathrm{~h}$. After cooling, the mixture was poured into water and extracted with EtOAc. The combined extracts were washed with water, dried over $\mathrm{Na}_{2} \mathrm{SO}_{4}$. After removal of the solvent in vacuo, the residue was separated by column chromatography with hexane/EtOAc $(6: 1)$ as eluent to give the dialkoxybenzaldehyde. Formylation of 1,4-diphenoxybenzene with HMTA gave 14 and 15 instead of the desired compound $\mathbf{1 2 b}$.

2,4-Diethoxybenzaldehyde (10a). $\left(\mathrm{CH}_{3} \mathrm{COOH} / \mathrm{H}_{2} \mathrm{O}=100 / 20 \mathrm{~mL}\right)$; Colorless needles; Yield, 48\%; mp 69-70 ${ }^{\circ} \mathrm{C}\left(\mathrm{mp}^{16 \mathrm{~d}} 68-71{ }^{\circ} \mathrm{C}\right) ;{ }^{1} \mathrm{H}$ NMR : $\delta$ 1.40-1.48 (m, 6H), 4.04-4.12 (m, 4H), $6.40(\mathrm{~s}$, $1 \mathrm{H}), 6.49$ (d, $J=8.7 \mathrm{~Hz}, 1 \mathrm{H}), 7.78(\mathrm{~d}, J=8.7 \mathrm{~Hz}, 1 \mathrm{H}), 10.31(\mathrm{~s}, 1 \mathrm{H}) ;{ }^{13} \mathrm{C} \mathrm{NMR}: \delta 14.4,14.5$, 63.8, 63.9, 98.7, 106.1, 118.7, 130.0, 163.0, 165.4, 188.2.

2,4-Diphenoxybenzaldehyde (10b). $\left(\mathrm{CF}_{3} \mathrm{COOH} / \mathrm{CH}_{3} \mathrm{COOH}=130 / 130 \mathrm{~mL}\right)$; Colorless needles; Yield, 57\%; mp 52-53 ${ }^{\circ} \mathrm{C} ;{ }^{1} \mathrm{H}$ NMR : $\delta 6.46(\mathrm{~s}, 1 \mathrm{H}), 6.65(\mathrm{~d}, J=6.7 \mathrm{~Hz}, 1 \mathrm{H}), 7.00-7.18(\mathrm{~m}, 6 \mathrm{H})$, 7.31-7.39 (m, 4H), $7.88(\mathrm{~d}, J=8.7 \mathrm{~Hz}, 1 \mathrm{H}), 10.39(\mathrm{~s}, 1 \mathrm{H}) ;{ }^{13} \mathrm{C} \mathrm{NMR}: \delta 106.8,111.9,119.4$, $120.2,121.8,124.5,124.9,130.0,130.04,130.2$, 54.7, 155.8, 161.7, 164.1, 187.8. Anal. Calcd for $\mathrm{C}_{19} \mathrm{H}_{14} \mathrm{O}_{3}$ : C, 78.60; $\mathrm{H}, 4.87$. Found: C, 78.97; $\mathrm{H}, 4.87$.

2,5-Diethoxybenzaldehyde (12a). $\left(\mathrm{CF}_{3} \mathrm{COOH} / \mathrm{CH}_{3} \mathrm{COOH}=30 / 90 \mathrm{~mL}\right)$; Yield, 34\%; mp 61$62{ }^{\circ} \mathrm{C}\left(\mathrm{mp}^{18} 60-61{ }^{\circ} \mathrm{C}\right) ;{ }^{1} \mathrm{H}$ NMR : $\delta 1.36-1.46(\mathrm{~m}, 6 \mathrm{H}), 4.00(\mathrm{q}, J=6.9 \mathrm{~Hz}, 2 \mathrm{H}), 4.09(\mathrm{q}, J=6.9$ $\mathrm{Hz}, 2 \mathrm{H}), 6.91(\mathrm{~d}, J=9.0 \mathrm{~Hz}, 1 \mathrm{H}), 7.05-7.11(\mathrm{~m}, 1 \mathrm{H}), 7.29(\mathrm{~d}, J=3.0 \mathrm{~Hz}, 1 \mathrm{H}), 10.46(\mathrm{~s}, 1 \mathrm{H}) ;{ }^{13} \mathrm{C}$ NMR : $\delta 14.6,63.9,64.7,110.8,114.3,123.9,125.0,152.7,156.0,189.6$.

4-(4-Phenoxyphenoxy)benzaldehyde (14). $\left(\mathrm{CF}_{3} \mathrm{COOH} / \mathrm{CH}_{3} \mathrm{COOH}=60 / 50 \mathrm{~mL}\right)$; Colorless needles; Yield, < 10\%; mp 47-48 ${ }^{\circ} \mathrm{C}\left(\mathrm{mp}^{19} 46-48{ }^{\circ} \mathrm{C}\right) ;{ }^{1} \mathrm{H}$ NMR : $\delta$ 7.02-7.14 (m, 9H), 7.33-7.38 $(\mathrm{m}, 2 \mathrm{H}), 7.85(\mathrm{~d}, J=8.7 \mathrm{~Hz}, 2 \mathrm{H}), 9.91(\mathrm{~s}, 1 \mathrm{H}) .{ }^{13} \mathrm{C} \mathrm{NMR}: \delta 117.1,118.7,120.3,121.8,123.4$, $129.8,131.1,131.9,150.3,154.2,157.1,163.5,190.7$.

4-[4-(4-Formylphenoxy)phenoxy]benzaldehyde (15). Colorless needles; Yield, < 10\%; mp 157-158 ${ }^{\circ} \mathrm{C}\left(\mathrm{mp}^{19} 157-158{ }^{\circ} \mathrm{C}\right) ;{ }^{1} \mathrm{H}$ NMR : $\delta 7.08$ (d, $\left.J=8.2 \mathrm{~Hz}, 4 \mathrm{H}\right), 7.14(\mathrm{~s}, 4 \mathrm{H}), 7.86(\mathrm{~d}, J=$ $8.2 \mathrm{~Hz}, 4 \mathrm{H}), 9.94$ (s, 2H). ${ }^{13} \mathrm{C}$ NMR : $\delta 117.5,122.0,131.4,132.0,151.8,163.0,190.6$.

Method B. An appropriate dihydroxybenzaldehyde $(20 \mathrm{mmol})$ was mixed with an alkyl bromide (46 mmol) in the presence of $\mathrm{K}_{2} \mathrm{CO}_{3}$ (anhydrous, $14 \mathrm{~g}$ ). The reaction temperature, time and solvent are given below. After cooling, the mixture was poured into water and extracted with EtOAc. The combined extracts were washed with water, dried over $\mathrm{Na}_{2} \mathrm{SO}_{4}$. After removal of the solvent in vacuo, the residue was separated by column chromatography with hexane/EtOAc $(3: 1)$ as eluent to give the dialkoxybenzaldehyde. Alkylation of 3,4-dihydroxybenzaldehyde with $\mathrm{ClCH}_{2} \mathrm{CH}_{2} \mathrm{Br}$ gave 13 instead of the desired compound 11d.

2,4-Bis(benzyloxy)benzaldehyde (10c). (Reflux, 6 h; BuOH 30 mL); Colorless needles; Yield, 67\%; mp 87-88 ${ }^{\circ} \mathrm{C}\left(\mathrm{mp}^{16 \mathrm{c}} 87-88{ }^{\circ} \mathrm{C}\right) ;{ }^{1} \mathrm{H}$ NMR : $\delta 5.05$ (s, 2H), 5.08 (s, 2H), 6.57 (s, 1H), 6.59 (d, 
$J=8.3 \mathrm{~Hz}, 1 \mathrm{H}), 7.34-7.38(\mathrm{~m}, 10 \mathrm{H}), 7.81(\mathrm{~d}, J=8.3 \mathrm{~Hz}, 1 \mathrm{H}), 10.37(\mathrm{~s}, 1 \mathrm{H}) ;{ }^{13} \mathrm{C} \mathrm{NMR}: \delta 70.2$, 99.9, 106.9, 119.3, 127.2, 127.4, 128.15, 128.2, 128.6, 130.3, 135.8, 162.6, 165.1, 188.0.

2,4-Bis(2-chloroethoxy)benzaldehyde (10d). (reflux, $20 \mathrm{~h} ; \mathrm{CH}_{3} \mathrm{COCH}_{3} 60 \mathrm{~mL}$ ); Colorless needles; Yield, 51\%; mp 80-81 ${ }^{\circ} \mathrm{C} ;{ }^{1} \mathrm{H}$ NMR : $\delta$ 3.82- $3.90(\mathrm{~m}, 4 \mathrm{H}), 4.28-4.34(\mathrm{~m}, 4 \mathrm{H}), 6.47$ (s, 1H), 6.57 (d, $J=8.7 \mathrm{~Hz}, 1 \mathrm{H}), 7.82$ (d, $J=8.5 \mathrm{~Hz}, 1 \mathrm{H}), 10.35(\mathrm{~s}, 1 \mathrm{H}) ;{ }^{13} \mathrm{C} \mathrm{NMR}: \delta 41.5,68.2$, 68.4, 99.7, 106.6, 119.7, 130.4, 162.1, 164.4, 187.9. Anal. Calcd for $\mathrm{C}_{11} \mathrm{H}_{12} \mathrm{O}_{3}: \mathrm{C}, 50.21 ; \mathrm{H}, 4.61$. Found: C, 50.22; H, 4.58 .

2,4-Bis(2-propynyloxy)benzaldehyde (10e). (80 ${ }^{\circ} \mathrm{C}, 2.5 \mathrm{~h}$; DMF $\left.80 \mathrm{~mL}\right)$; Colorless needles; Yield, 90\%; mp 113-114 ${ }^{\circ} \mathrm{C}\left(\mathrm{mp}^{18} 110{ }^{\circ} \mathrm{C}\right) ;{ }^{1} \mathrm{H}$ NMR d (DMSO): 3.16 (s, 1H), 3.17 (s, 1H), 4.84 (s, 2H), $4.90(\mathrm{~s}, 2 \mathrm{H}), 6.69(\mathrm{~d}, J=8.6 \mathrm{~Hz}, 1 \mathrm{H}), 6.78(\mathrm{~s}, 1 \mathrm{H}), 7.73(\mathrm{~d}, J=8.6 \mathrm{~Hz}, 1 \mathrm{H}), 10.23(\mathrm{~s}$, $1 \mathrm{H}) ;{ }^{13} \mathrm{C}$ NMR $\delta(\mathrm{DMSO}): 55.8,56.2,77.5,77.6,77.8,100.1,107.5,119.1,129.5,161.0,163.3$, 187.0.

3,4-Bis(2-propynyloxy)benzaldehyde (11e). (80 ${ }^{\circ} \mathrm{C}, 2.5 \mathrm{~h}$; DMF $80 \mathrm{~mL}$ ); Colorless needles; Yield, 74\%; mp 105-106 ${ }^{\circ} \mathrm{C} ;{ }^{1} \mathrm{H}$ NMR $\delta(\mathrm{DMSO}): 3.59$ (s, 2H), 4.93 (s, 2H), 4.97 (s, 2H), 7.28 (d, $J=7.4 \mathrm{~Hz}, 1 \mathrm{H}), 7.55$ (s, 1H), 7.63 (d, $J=7.8 \mathrm{~Hz}, 1 \mathrm{H}), 9.87$ (s, 1H); ${ }^{13} \mathrm{C}$ NMR d (DMSO): 56.2, 56.4, 78.7, 78.9, 79.1, 112.0, 113.4, 126.7, 130.3, 147.3, 152.3, 191.7. Anal. Calcd for $\mathrm{C}_{13} \mathrm{H}_{10} \mathrm{O}_{3}$ : C, 72.88; H, 4.71. Found: C, 73.12; H, 4.71.

2,5-Bis(benzyloxy)benzaldehyde (12c). (reflux, 6 h; BuOH $30 \mathrm{~mL}$ ); Colorless needles; Yield, 35\%; mp 89-91 ${ }^{\circ} \mathrm{C} ;{ }^{1} \mathrm{H}$ NMR: $\delta 5.01(\mathrm{~s}, 2 \mathrm{H}), 5.10(\mathrm{~s}, 2 \mathrm{H}), 6.97(\mathrm{~d}, J=9.1 \mathrm{~Hz}, 1 \mathrm{H}), 7.13-7.17$ (m, $1 \mathrm{H}), 7.30-7.43(\mathrm{~m}, 11 \mathrm{H}), 10.50(\mathrm{~s}, 1 \mathrm{H}) ;{ }^{13} \mathrm{C}$ NMR : $\delta 70.5,71.1,111.5,114.9,124.1,125.4$, $127.3,127.5,128.0,128.2,128.5,128.6,136.2,136.5,152.9,155.8,189.3$.

2,5-Bis(2-propynyloxy)benzaldehyde (12e). (80 ${ }^{\circ} \mathrm{C}$, $2.5 \mathrm{~h}$; DMF $\left.80 \mathrm{~mL}\right)$; Colorless needles; Yield, 71\%; mp 91- $92{ }^{\circ} \mathrm{C}$; ${ }^{1} \mathrm{H}$ NMR $\delta$ (DMSO): 3.43 (s, 1H), 3.50 (s, 1H), $4.80(\mathrm{~s}, 2 \mathrm{H}), 4.92$ (s, 2H), 7.28- $7.30(\mathrm{~m}, 3 \mathrm{H}), 10.34(\mathrm{~s}, 1 \mathrm{H}) ;{ }^{13} \mathrm{C}$ NMR $\delta$ (DMSO): 56.0, 57.1, 78.1, 78.5, 78.6, 78.8, 111.8, 116.2, 123.6, 125.4, 151.7, 154.5, 188.5. Anal. Calcd for $\mathrm{C}_{13} \mathrm{H}_{10} \mathrm{O}_{3}$ : C, 72.88; H, 4.71. Found: C, 72.65; H, 4.74 .

2,3-Dihydro-1,4-benzodioxine-6-carboxaldehyde (13). (reflux, 2- $6 \mathrm{~h}$; DMF or $\mathrm{CH}_{3} \mathrm{COCH}_{3} 60$ $\mathrm{mL})$; Colorless needles; Yield, 55\%; mp 51-52 ${ }^{\circ} \mathrm{C}\left(\mathrm{mp}^{20} 50-51{ }^{\circ} \mathrm{C}\right) ;{ }^{1} \mathrm{H}$ NMR : $\delta 4.28(\mathrm{~d}, J=4.2$ $\mathrm{Hz}, 2 \mathrm{H}), 4.31(\mathrm{~d}, J=4.1 \mathrm{~Hz}, 2 \mathrm{H}), 6.95(\mathrm{~d}, J=8.8 \mathrm{~Hz}, 1 \mathrm{H}), 7.37-7.39(\mathrm{~m}, 2 \mathrm{H}), 9.80(\mathrm{~s}, 1 \mathrm{H}) ;{ }^{13} \mathrm{C}$ NMR : $\delta 63.9,64.5,117.6,118.1,124.0,130.4,143.8,149.1,190.5$. 


\section{References}

1. Katritzky, A. R.; Cui, X.; Long, Q.; Yang, B.; Zhang, Y. K.; Wilcox, A. Org. Prep. Proced. Int. 2000, 32, 175.

2. (a) Ghaisas, V. V. J. Org. Chem. 1957, 22, 703. (b) Campaigne, E.; Neiss, E. S. J. Heterocyclic Chem. 1966, 3, 46. (c) Hiroya, K.; Hashimura, K.; Ogasawara, K. Heterocycles 1994, 38, 2463.

3. (a) King, W. J.; Nord, F. F. J. Org. Chem. 1948, 18, 635. (b) Weston, A. W.; Michaels, R. J., Jr. J. Am. Chem. Soc. 1950, 72, 1422. (c) Weston, A. W.; Michaels, R. J., Jr. Org. Synth.1963, 4, 915.

4. (a) Sargent, M. V.; Dean, F. M. In Comprehensive Heterocyclic Chemistry; Katritzky, A. R., Rees, C. W., Eds; Pergamon Press: Oxford; Vol. 4, p 651. (b) Campaigne, E. In Comprehensive Heterocyclic Chemistry; Katritzky, A. R.: Rees, C. W., Eds; Pergamon Press: Oxford, 1984; Vol. 4, p. 918 and 921.

5. Bisagni, M.; Buu-Hoi, N. P.; Royer, R. J. Chem. Soc. 1955, 3688.

6. Shirley, D. A.; Danzig, M. J. J. Am. Chem. Soc. 1952, 74, 2935.

7. Baris, M. L.; Wahl, H. Bull. Soc. Chim. Fr. 1959, 342.

8. Ebdrup, S.; Jensen, M. S.; Vedso, P. J. Chem. Soc., Perkin Trans. I 1998, 351.

9. Suu, M. V. T.; Buu-Hoi, N. P.; Xuong, N. D. Bull. Soc. Chim. Fr. 1962, 1875.

10. Dickinson, R. P.; Iddon, B. J. Chem. Soc.(C) 1971, 182. (b) Dickinson, R. P.; Iddon, B. J. Chem. Soc.(C) 1970, 2592.

11. Hawthorne, D. G.; Porter, Q. N. Aust. J. Chem. 1966, 19, 1909.

12. Ebdrup, S. J. Chem. Soc., Perkin Trans. I 1998, 1147.

13. Duff, J. C. J. Chem. Soc. 1941, 547.

14. Sukuzi, Y.; Takahashi, H. Chem. Pharm. Bull. 1983, 31, 1751.

15. (a) Larrow, J. F.; Jacobsen, E. N.; Gao, Y.; Hong, Y.; Nie, X.; Zepp, C. M. J. Org. Chem.1994, 59, 1939. (b) Petrov, O. I.; Kalcheva, V. B.; Antonova, A. T. Collect. Czech. Chem. Commun.1997, 62, 494. (c) Crozet, M. P.; Sabuco, J. F.; Tamburlin, I.; Barreau, M.; Giraud, L.; Vanelle, P. Heterocycles 1993, 36, 45. (d) Ubeda, J. I.; Avendano, C.; Menendez, J. C.; Villacampa, M. Heterocycles 1994, 38, 2677. (e) Weidner-Wells, M. A.; Fraga-Spano, S. A. Synth. Commun. 1996, 26, 2775.

16. (a) Loev, B.; Dawson, C. R. J. Am. Chem. Soc. 1956, 78, 6095. (b) Reimann, E. Chem. Ber. 1969, 2881. (c) Kimachi, T.; Tanaka, K.; Yoneda, F. J. Heterocyclic Chem. 1991, $28,439$. (d) Robinson, R.; Shah, R. C. J. Chem Soc. 1934, 1491.

17. Faulques, M.; Rene, L.; Royer, R.; Averbeck, D.; Moradi, M. Eur. J. Med. Chem. Chim. Ther. 1983, 18, 9.

18. Thompson, M.; Whelan, J.; Zemon, D. J.; Bosnich, B.; Solomon, E. I.; Gray, H. B. J. Am. Chem. Soc. 1979, 101, 2483. 
19. Yeager, G. W.; Schissel, D. N. Synthesis 1991, 63.

20. Baddeley, G.; Smith, N. H. P. J. Chem. Soc. 1961, 2516. 